\title{
Adamalizyny jako potencjalne biomarkery w wybranych nowotworach złośliwych przewodu pokarmowego
}

Magdalena Sikora-Skrabaka*1,2, Katarzyna Walkiewicz ${ }^{2}$, Ewa Nowakowska-Zajdel ${ }^{1,2}$

${ }^{1}$ Zakład Profilaktyki Chorób Żywieniowozależnych, Katedra Profilaktyki Chorób Metabolicznych, Wydział Nauk o Zdrowiu w Bytomiu, Śląski Uniwersytet Medyczny w Katowicach

${ }^{2}$ Oddział Onkologii Klinicznej, Wojewódzki Szpital Specjalistyczny nr 4 w Bytomiu

Abstrakt

Nowotwory złośliwe przewodu pokarmowego zajmują czołowe miejsce zarówno wśród przyczyn zachorowań jak i zgonów z powodu chorób nowotworowych na świecie. Wciąż poszukuje się potencjalnych biomarkerów, które mogłyby posłużyć jako czynniki predykcyjne i prognostyczne w tych nowotworach. Wśród białek, które mogłyby pełnić taką rolę, wymienia się adamalizyny. Liczne białka z tej rodziny są zaangażowane w wielu etapach nowotworzenia, od procesu różnicowania się pojedynczych komórek, wzrost i progresję guza do tworzenia przerzutów odległych. Dzieje się to m.in. poprzez ścieżki sygnałowe związane z aktywacją insulinopodobnych czynników wzrostu, naskórkowych czynników wzrostu czy oddziaływanie na czynnik martwicy nowotworu TNF-a. Szczególnie istotna w wyjaśnieniu patomechanizmu rozwoju raków gruczołowych przewodu pokarmowego wydaje się ścieżka sygnałowa związana z aktywacją cytokin prozapalnych. Przewlekły stan zapalny jest bowiem dobrze udokumentowanym czynnikiem ryzyka rozwoju tej grupy chorób nowotworowych.

Poznanie roli białek z rodziny adamalizyn w rozwoju i patogenezie nowotworów złośliwych przewodu pokarmowego wymaga wciąż dalszych badań. $W$ artykule podjęto próbę syntezy aktualnej wiedzy na temat wykorzystania wybranych białek z rodziny adamalizyn jako biomarkerów nowotworów złośliwych przewodu pokarmowego.

Słowa

kluczowe adamalizyny• nowotwory złośliwe przewodu pokarmowego • biomarkery

Otrzymano: 05.05.2020, Zaakceptowano: 25.05.2021

Abstract

Gastrointestinal cancers are one of the most common causes of cancers and cancer-related mortality worldwide. Potential biomarkers that could serve as predictive and prognostic factors in these cancers are still being sought. Adamalysines are mentioned among the proteins that could play such a role. Numerous proteins from this family are involved in the many stages of tumor formation: from the process of individual cell differentiation, through tumor growth and progression, to the formation of distant metastases. This process occurs, among others, through signaling pathways associated with the activation of insulin-like growth factors, epidermal growth factors or the effect on tumor necrosis factor TNF- $\alpha$. The signal pathway associated with the activation of proinflammatory cytokines seems to be particularly important in explaining the pathomechanism of gastrointestinal adenocarcinomas. Chronic inflammation is a well-documented risk factor for the development of this group of cancer diseases.

Understanding the role of adamalysines protein family in the development and pathogenesis of gastrointestinal malignancies still requires further research. The article attempts to synthesize current knowledge on the use of selected proteins from the adamalysin family as biomarkers for gastrointestinal cancers.

\section{Keywords}

adamalisynes $\cdot$ gastrointestinal cancers $•$ biomarkers

Received: 05.05.2020, Accepted: 25.05.2021

*Corresponding author e-mail: magda_sikora19@wp.pl

(๔) Br.NC-ND ( 2021 Magdalena Sikora-Skrabaka et al. This work is licensed under the Creative Commons Attribution-NonCommercial-NoDerivs 4.0 License. 


\section{Wstęp}

Według danych epidemiologicznych, nowotwory złośliwe przewodu pokarmowego na świecie stanowią najliczniejszą grupę rozpoznawanych nowotworów, jednocześnie zajmując pierwsze miejsce wśród przyczyn zgonów z powodów onkologicznych [1].

Mimo wielu lat badań nad nowotworzeniem, wciąż poszukuje się swoistych i czułych biomarkerów nowotworów złośliwych przewodu pokarmowego, możliwych do wykorzystania jako czynniki prognostyczne lub predykcyjne, a także na etapie wczesnej, nieinwazyjnej diagnostyki i monitorowania przebiegu choroby. Wśród białek ewentualnie spełniających taką rolę od prawie 15 lat wymienia się adamalizyny [2]. Adamalizyny to grupa wielodomenowych białek transbłonowych, o aktywności enzymów proteolitycznych, które biorą udział w regulacji wielu procesów m.in.: adhezji i migracji komórkowej, sygnalizacji międzykomórkowej, regulacji biodostępności czynników wzrostu i cytokin, proteolizie macierzy międzykomórkowej. Procesy te mają znaczenie zarówno w utrzymywaniu homeostazy organizmu człowieka, jak i odgrywają istotną rolę w patomechanizmie nowotworzenia i progresji chorób nowotworowych przez bezpośrednie zaangażowanie w powstawanie przerzutów odległych [3].

Wśród ścieżek sygnałowych zależnych od białek z rodziny ADAM, zaangażowanych w patomechanizm nowotworzenia, wymienia się szlaki aktywacji insulinopodobnych czynników wzrostu [4], VEGF, FGF, EGRF oraz związanych bezpośrednio z aktywacją przewlekłych procesów zapalnych, przez oddziaływanie m.in. na TNF- $\alpha[5,6,7,8]$. Ścieżka sygnałowa związana z aktywacją cytokin prozapalnych wydaje się szczególnie istotna w wyjaśnieniu patomechanizmu rozwoju gruczolakoraków przewodu pokarmowego, dla których przewlekły stan zapalny jest dobrze udokumentowanym czynnikiem ryzyka. Wzajemne powiązanie aktywności wybranych adamalizyn i cytokin prozapalnych można stwierdzić na podstawie obserwacji wskazującej, że adamalizyny mogą zmieniać szlaki sygnalizacyjne komórek w zależności od zmian w ich środowisku pozakomórkowym, np. w odpowiedzi na czynniki zapalne. W stanach zapalnych czy uszkodzenia nabłonka jelitowego aktywność ADAM jest podwyższona. Czynniki prozapalne stymulują aktywność proteolityczną tej rodziny białek. Zwiększona aktywność ADAM wpływa na proces usunięcia stanu zapalnego oraz odbudowy i regeneracji nabłonka. Jednak w warunkach przewlekłego i nawracającego stanu zapalnego, te same sygnały wielokrotnie powtarzane, mogą zwiększać ryzyko nowotworzenia związanego z zapaleniem [9].

W artykule autorzy podjęli próbę syntezy aktualnej wiedzy na temat możliwości wykorzystania wybranych białek z rodziny adamalizyn jako biomarkerów nowotworów złośliwych przewodu pokarmowego, koncentrując się w sposób szczególny na powiązaniu aktywności białek ADAM z utrzymywaniem przewlekłego stanu zapalnego wywołującego kancerogenezę.

\section{Rola wybranych adamalizyn w nowotworach złośliwych przewodu pokarmowego}

\section{Rak przełyku}

W dotychczas opisanych badaniach eksperymentalnych wskazywano na rolę m.in. białek ADAM9, ADAM12 i ADAM17 w patogenezie raka przełyku. Jednym z potencjalnych szlaków biorących udział w tym procesie może być ścieżka związana z białkami ADAM12 i przedstawicielami tzw. rodziny tetraspanin, zwłaszcza TM4SF3. Aktywacja tetraspanin, które $\mathrm{w}$ organizmie odpowiadają m.in. za procesy integracji komórkowej i przekaźnictwa sygnałów odbywa się z udziałem (lub - przy udziale) białka ADAM12. W badaniach materiału tkankowego wykazano, że zmniejszenie ekspresji wybranych tetraspanin przez zastosowanie przeciwciała przeciw białku ADAM12 znacząco ogranicza inwazyjność komórek raka płaskonabłonkowego przełyku. Stąd hipoteza, że zwiększona aktywność ADAM12 może pełnić rolę w tworzeniu przerzutów i inwazji nowotworowej [10]. Liu i wsp. wykazali natomiast, że ekspresja ADAM17 była znacząco wyższa w tkance raka płaskonabłonkowego przełyku niż w zdrowej, a poziom ekspresji koreluje z klinicznym zaawansowaniem choroby, w tym obecnością zmian odległych [11]. Istotna wydaje się także rola adamalizyn w utrzymaniu homeostazy mikrośrodowiska nowotworu. W badaniu na modelach zwierzęcych stwierdzono, że aktywacja ADAM9 jest związana z procesami angiogenezy, prawdopodobnie przez modulację szlaków VEGF [12]. Znaczenie białka ADAM9 wymienia się także dla patogenezy raka gruczołowego przełyku, rozwijającego się na podłożu przełyku Barretta, gdyż w tkankach pochodzących z guza obserwowano jego wysoką ekspresję [13].

\section{Rak żołądka}

Analizując dostępne doniesienia, istotne również wydaje się znaczenie białek ADAM10 i ADAM17 w rozwoju i progresji raka żołądka. Szczególnie ważne są dane dotyczące powiązania między aktywacją tych białek a obecnością przewlekłego procesu zapalnego związanego bezpośrednio z infekcją Helicobacter pylori.

W jednym z dostępnych badań wykazano, że infekcja H. pylori była związana z wysokim poziomem ekspresji ADAM10 i ADAM17; wysoki poziom transkryptów tych białek stwierdzono także w gruczolakoraku żołądka, co może 
wskazywać, że przewlekła infekcja $H$. pylori przyczynia się do wzrostu poziomu wspomnianych białek z rodziny ADAM w tkance żołądka i przez to przyczynia się do nowotworzenia [14].

Inne doniesienie wskazuje, że dodatnia ekspresja ADAM10 w raku żołądka korelowała $z$ wiekiem, wielkością guza, głębokością naciekania, inwazją naczyń, zajęciem węzłów chłonnych, obecnością przerzutów odległych, a także stopniem zaawansowania według klasyfikacji TNM. Stwierdzono zatem, że wysoka ekspresja ADAM10 była złym czynnikiem prognostycznym, a pięcioletnie przeżycia całkowite $w$ grupie chorych $z$ wysoką ekspresją ADAM10 były znacząco niższe u pacjentów $z$ wysoką ekspresją tego białka [15]. Podobną zależność wykazano dla ADAM17, jego zwiększona ekspresja korelowała z głębokością inwazji, stopniem różnicowania komórek, przerzutami w węzłach chłonnych, przerzutami odległymi, stadium według klasyfikacji TNM, a także agresywną progresją raka żołądka oraz złym rokowaniem [16, 17]. Obserwację wydaje się potwierdzać inne badanie, w którym oceniano ekspresję ADAM17 w tkance żołądka po zabiegu gastrektomii, przeprowadzonej z powodu raka żołądka. Wykazano bowiem, że u tych pacjentów, u których poziom ekspresji ADAM17 $w$ tkance nowotworu był wysoki, czas przeżycia wolnego od progresji (PFS) był znacząco krótszy niż u pacjentów z niskim poziomem tej ekspresji (16,6 vs. 44,2 miesięcy), taką samą zależność obserwowano dla czasu przeżycia całkowitego (OS) $(26,9$ vs 49,6 miesięcy) [18].

Dalsze badania wykazały, że wysoki poziom ekspresji ADAM17 może powodować progresję raka żołądka, potencjalnie poprzez ścieżkę sygnałową Notch i/lub Wnt [19]. Ważnym szlakiem sygnałowym proliferacji komórek raka żołądka wydaje się również szlak związany z naskórkowopodobnym czynnikiem wzrostu (EGF) - wzrost ekspresji ADAM17, stymulowany przez transformujący czynnik wzrostu (TGF- $\beta$ ), powoduje jego transaktywację i wzrost proliferacji komórek nowotworowych [20].

Inne badanie wskazuje, że ADAM17 prawdopodobnie uczestniczy w patogenezie GIST żołądka przez wspomnianą ścieżkę sygnałową związaną z EGFR [21].

Poza ADAM10 i ADAM17, znacząco wyższą ekspresję w tkance gruczolakoraka żołądka wykazywały także ADAM9, 12 i 15, ponadto ekspresja ADAM12 była wyższa w tkance raka żołądka typu jelitowego niż w typie rozlanym [22]. Także ADAM33 wydaje się pełnić rolę $w$ patogenezie raka żołądka przez regulację wydzielania IL-18, powodując zwiększoną migrację i proliferację komórek [23]. W badaniach na modelach tkankowych wykazano, że ważną rolę w proliferacji i inwazji komórek raka żołądka odgrywa ADAM9, a w komórkach, w których poziom ekspresji tego białka był wysoki, obserwowano dobrą reakcję na zastosowanie swoistego przeciwciała anty-ADAM9 [24]. W innym badaniu wskazano także, że poziom ekspresji ADAM9 był skorelowany z wielkością guza, lokalną inwazją nowotworu, obecnością przerzutów w węzłach chłonnych oraz stopniem zaawansowania według klasyfikacji TNM [25]. Innym przedstawicielem z rodziny adamalizyn, który może pełnić rolę w patogenezie gruczolakoraka żołądka jest ADAM8. Wysoka ekspresja tego białka $w$ tkance nowotworu koreluje $z$ cechą $\mathrm{T}$ (wielkością guza pierwotnego), N (obecnością przerzutów w węzłach chłonnych), inwazją naczyń, a także krótszym czasem przeżycia całkowitego. Badania in vitro wykazały, że prawdopodobnym mechanizmem powodującym wzrost guza, zwiększonej migracji komórek oraz inwazji naczyń w tym przypadku jest zmniejszenie poziomu kinazy p-ERK [26]. Także stężenie ADAM8 we krwi pacjentów zarówno z wczesnym jak i zaawansowanym gruczolakorakiem żołądka było znacząco wyższe w porównaniu do osób zdrowych. Ponadto stwierdzono, że stężenie ADAM8 we krwi ma wyższą wartość diagnostyczną niż oznaczenie CEA [27]. Potencjalnym biomarkerem w gruczolakoraku żołądka jest ADAM29, której wysoki poziom korelował w badaniach ze stopniem zaawansowania nowotworu według klasyfikacji TNM oraz czasem przeżycia całkowitego i wolnego od progresji, wyższy poziom ADAM29 był związany z gorszym rokowaniem [28].

\section{Rak trzustki}

Z punktu widzenia epidemiologicznego istotne są również analizy, w których podjęto próbę ustalenia szlaków patogenetycznych rozwoju raka trzustki. Jest to nowotwór charakteryzujący się szczególnie agresywnym przebiegiem. Według danych z 2018 r., na świecie zanotowano niemal tyle samo zgonów (432 tys.) co nowych zachorowań (459 tys.) z powodu gruczolakoraka trzustki [1], a jedynie $24 \%$ pacjentów przeżywa 1 rok od rozpoznania tego nowotworu, a przeżycia 5-letnie nie przekraczają $9 \%[29,30]$.

Podobnie jak w raku przełyku i żołądka w aktualnych doniesieniach wskazuje się na rolę białek ADAM10 i ADAM17 w rozwoju gruczolakoraków trzustki; znaczenie przypisuje się też białkom ADAM8 i ADAM9. Już w 2010 r. wykazano zwiększoną ekspresję adamalizyny ADAM10 u chorych na gruczolakoraka przewodowego w stosunku do zdrowych osób, obserwacje te potwierdzono też w badaniach na liniach komórkowych, gdzie ponadto wskazano, że wyciszenie ekspresji ADAM10 przez zastosowanie technik inżynierii genetycznej istotnie redukuje inwazyjność i zdolność proliferacji komórek nowotworowych [31]. W innym badaniu dostarczono dowodów na udział białka ADAM17 w procesie progresji zmian nowotworowych trzustki, od etapów wczesnych, prekursorowych do zaawansowanych postaci inwazyjnych [32].

Rola białek ADAM8 i ADAM9 wydaje się związana z odpowiedzią na hipoksję komórkową, a białka te mają 
prawdopodobny udział w procesach progresji guza przez wpływ na neoangiogenezę, migrację komórkową i dalszy wzrost skupisk komórek niezależnie od ich zakotwiczenia w macierzy. Pierwsze badania nad rolą ADAM8 w raku trzustki dostarczyły informacji o tym, że jego zwiększona ekspresja ma wpływ na inwazyjność tego nowotworu oraz koreluje z gorszym rokowaniem wyrażonym jako krótszy czas przeżycia całkowitego chorych [33]. W badaniach na liniach komórkowych wykazano związek między zwiększoną ekspresją zarówno mRNA, jak i białka ADAM8 w komórkach raka trzustki narażonych na hipoksję [34], ponadto białka te wykazywały efekt immunomodulujący, wpływając na napływ i aktywację makrofagów do mikrośrodowiska guza [35]. Mechanizm ten wyjaśnia także obserwację możliwego wpływu propofolu na zależną od niedotlenienia komórkowego ekspresję białka ADAM8 w komórkach gruczolakoraka trzustki [36].

Szczególnie wysoki poziom ekspresji białka ADAM9 jest stwierdzany w nowotworach o niskim stopniu zróżnicowania, co ma bezpośrednie znaczenie prognostyczne: u chorych z wysokim poziomem ekspresji ADAM9 wykazano szybszy postęp choroby, w tym skrócenie czasu przeżycia całkowitego, mimo wykonania zabiegu operacyjnego, resekcji R0, w porównaniu do pacjentów podobnie leczonych, ale z niską aktywnością adamalizyny ADAM9 [37]. Ponadto $\mathrm{w}$ badaniach in vitro $\mathrm{i}$ in vivo przedstawiono rolę ADAM9 w progresji raka trzustki poprzez kierowanie takimi procesami jak angiogeneza, migracja komórek, adhezja do macierzy zewnątrzkomórkowej czy wzrost guza niezależny od zakotwiczenia. Procesy te prawdopodobnie - przynajmniej w części - są związane ze ścieżką sygnałową EGFR/MEK/ ERK [38].

Poza wymienionymi wyżej białkami stwierdzono także, że zwiększona ekspresja adamalizyny ADAM15 $w$ tkance guza koreluje dodatnio $z$ obecnością przerzutów do regionalnych węzłów chłonnych. Szczególnie istotna wydaje się obserwacja wyjaśniająca jeden z elementów skutecznej odpowiedzi na terapię $\mathrm{w}$ raku gruczołowym trzustki. Stwierdzono, że gemcytabina hamuje wzrost komórek raka trzustki m.in. poprzez supresję białka ADAM15 [39]. Dzięki tej obserwacji i danych wskazujących na rolę adamalizyn w patogenezie gruczolakoraka trzustki poszukuje się potencjalnych punktów uchwytu terapii tego nowotworu. W jednym z badań wykazano, że zastosowanie blokera kanału wapniowego, fendyliny, znacznie zmniejsza migrację, proliferację, inwazyjność oraz wzrost komórek raka trzustki przez hamowanie aktywności ADAM10 [40]. Innym obiecującym punktem uchwytu może być ADAM17. $W$ badaniach na modelach zwierzęcych wykazano, że immunologiczne zablokowanie ADAM17 przez zastosowanie swoistego przeciwciała spowalnia tempo progresji guza, a także wpływa negatywnie na złośliwe różnicowanie się zmian łagodnych [41]. Na modelu zwierzęcym wykazano także, że użycie swoistego inhibitora ADAM8: białka BK1361, znacząco zmniejsza masę guza, głębokość naciekania oraz ogranicza tworzenie przerzutów odległych [42].

\section{Rak jelita grubego}

Rak jelita grubego jest najczęstszym spośród nowotworów przewodu pokarmowego, stanowiąc przy tym drugą przyczynę zgonów wśród wszystkich chorób nowotworowych na świecie [1]. Istotne zatem wydaje się poszukiwanie nowych biomarkerów tego nowotworu.

W wielu dotychczasowych badaniach wykazano rolę adamalizyn w patogenezie tego nowotworu. Naszym zdaniem na szczególną uwagę zasługują badania, w których analizowano szlaki molekularne wyjaśniające mechanizmy współzależności między występowaniem zaburzeń metabolicznych a rozwojem raka jelita grubego, co od lat obserwowano w badaniach epidemiologicznych. Potwierdzonymi czynnikami ryzyka rozwoju raka jelita grubego są m.in. nieprawidłowy stylżycia powodujący otyłość, szczególnie o dystrybucji wisceralnej, współwystępowanie cukrzycy i wynikający z nich przewlekły stan zapalny. Ważną rolę $w$ omawianych procesach pełni białko ADAM17. Ze względu na swoją aktywność proteolityczną nazywane również proteiną TACE, uwalnia aktywny czynnik martwicy nowotworu TNF- $\alpha$, który bierze udział $w$ stymulacji i podtrzymaniu procesu zapalnego m.in. przez wytwarzanie innych cytokin, chemokin, cząsteczek adhezji śródbłonka, a także wzrost przepuszczalności naczyń $[43,44]$. Ponadto ADAM17 powoduje wzrost guza przez aktywację czynników wzrostowych z rodziny EGF [45], a także przez wpływ na angiogenezę i wydzielanie cytokin, takich jak IL-6, -10, -12, czy wspomniany wyżej TNF- $\alpha$ [46]. W badaniach na modelach zwierzęcych wykazano, że wyciszenie ekspresji ADAM17 zmniejsza wzrost guza [46]. Ponadto wykazano wyższą ekspresję mRNA ADAM17 $w$ raku jelita grubego z przerzutami do wątroby niż w guzach pierwotnych niedających takich przerzutów, co może wskazywać na istotną rolę ADAM17 $\mathrm{w}$ tworzeniu zmian przerzutowych w wątrobie [47]. Wykazano także, że mutacja w genie KRAS, występująca w części gruczolakoraków jelita grubego, jest związana $z$ aktywnością ADAM17, a hamowanie wzrostu komórek raka jelita grubego związanego z mutacją $w$ tym genie przez stosowanie inhibitorów MEK, jest związane właśnie $z$ hamowaniem aktywności ADAM17 [48]. Podejmowano również próby hamowania aktywności ADAM17 przez zastosowanie swoistego przeciwciała [49].

Rolę w patogenezie raka jelita grubego, przez modulowanie szlaków odpowiedzi zapalnej, odgrywa także adamalizyna ADAM10, wpływając na ścieżkę sygnałową białka Notch. Szlak sygnałowy białka Notch w warunkach fizjologii pomaga m.in. kontrolować uszkodzenie jelit oraz 
Tabela 1. Rola poszczególnych adamalizyn w wybranych nowotworach złośliwych przewodu pokarmowego, opracowanie własne

\begin{tabular}{|c|c|c|}
\hline Nowotwór złośliwy & Białka ADAM & Rola poszczególnych białek [piśmiennictwo] \\
\hline & ADAM9 & Angiogeneza poprzez VEGF [12] \\
\hline \multirow[t]{6}{*}{ Rak przełyku } & ADAM12 & Związek z przerzutowaniem [10] \\
\hline & ADAM17 & Nadekspresja w tkance guza, związek z przerzutami odległymi [11] \\
\hline & ADAM8 & Promocja wzrostu guza, zwiększona migracja komórek, inwazja naczyń poprzez p-ERK [26] \\
\hline & ADAM9 & Rola w proliferacji i inwazji komórek raka [24, 25] \\
\hline & ADAM10 & Związek z przewlekłą infekcją H. pylori; związek z inwazją naczyń i przerzutowaniem [14, 15] \\
\hline & ADAM12 & Nadekspresja w tkance guza [22] \\
\hline \multirow[t]{6}{*}{ Rak żołądka } & ADAM15 & Nadekspresja w tance guza [22] \\
\hline & ADAM17 & $\begin{array}{c}\text { Progresja poprzez ścieżkę Notch i/lub Wnt [19] i EGF [20]; związek z infekcją H. pylori [14]; związek z } \\
\text { inwazją miejscową oraz przerzutowaniem [16, 17] }\end{array}$ \\
\hline & ADAM29 & Korelacja ze stopniem zaawansowania [28] \\
\hline & ADAM33 & Zwiększona migracja i proliferacja przez IL-18 [23] \\
\hline & ADAM8 & $\begin{array}{l}\text { Wpływ na angiogenezę, migrację komórkową, inwazyjność; związek z odpowiedzią na hipoksję [33, } \\
\qquad 34,36]\end{array}$ \\
\hline & ADAM9 & $\begin{array}{l}\text { Angiogeneza, migracja komórek, wzrost guza związane ze ścieżką sygnałową EGFR/MEK/ERK; } \\
\qquad \text { związek z niskim stopniem różnicowania }[37,38]\end{array}$ \\
\hline \multicolumn{3}{|l|}{ Rak trzustki } \\
\hline & ADAM10 & Nadekspresja w tkance guza; inwazyjność, proliferacja komórek [31] \\
\hline & ADAM15 & Związek z przerzutowaniem do węzłów chłonnych [39] \\
\hline & ADAM17 & Udział w patogenezie od postaci prekursorowych do inwazyjnych [32] \\
\hline \multirow{8}{*}{ Rak jelita grubego } & ADAM8 & Nadekspresja w tkance guza [55] \\
\hline & ADAM9 & Nadekspresja w tkance guza; związek z reakcją desmoplastyczną [54, 56, 57] \\
\hline & ADAM10 & $\begin{array}{c}\text { Związek z zapaleniem przez ścieżkę Notch; wyższe stężenie w surowicy krwi; związek ze stopniem } \\
\text { zaawansowania }[50,51,52]\end{array}$ \\
\hline & ADAM12 & Związek z reakcją desmoplastyczną; nowotworzenie poprzez szlaki związane z IGF [4, 54] \\
\hline & ADAM15 & Zmniejszona ekspresja w tkance guza [58] \\
\hline & ADAM17 & $\begin{array}{c}\text { Związek z przewlekłym stanem zapalnym - uwalnianie TNFalfa [43, 44]; promocja wzrostu guza przez } \\
\text { EGF [45]; angiogeneza, wydzielanie cytokin prozapalnych [46]; związek z przerzutowaniem; wyższe } \\
\text { stężenie w surowicy krwi }[47,52]\end{array}$ \\
\hline & ADAM19 & Związek z microRNA-30c [61] \\
\hline & ADAM28 & Nowotworzenie poprzez szlaki związane z IGF [4, 53] \\
\hline
\end{tabular}


bierze udział w procesach naprawczych, w przypadku dysregulacji może doprowadzić do zapalenia jelit oraz inicjacji i progresji raka jelita grubego [50]. Już w 2005 r. wykazano korelację między ekspresją ADAM10 a stopniem zaawansowania raka jelita grubego [51]. Obserwacje te potwierdzają niedawne analizy, w których wykazano, że stężenie ADAM 10 i ADAM17 w surowicy krwi jest wyższe $\mathrm{u}$ chorych na raka jelita grubego, a także że stężenie to koreluje ze stopniem różnicowania komórek nowotworowych oraz obecnością przerzutów odległych [52].

Poza wpływem wybranych adamalizyn na szlak sygnałowy związany z EGFR w patogenezie gruczolakoraka jelita grubego, wybrane białka z tej rodziny mogą promować nowotworzenie przez aktywację szlaków związanych z insulinopodobnymi czynnikami wzrostu (IGF), co również znajduje odzwierciedlenie w danych epidemiologicznych. IGF należą do jednych z najsilniejszych czynników wzrostu o możliwości oddziaływania auto-, para- i endokrynnego. Białka ADAM12 i ADAM28 przez swoją aktywność proteolityczną, biorą bezpośredni udział w uwalnianiu aktywnych postaci IGF $[4,53]$.

Bardzo istotne są również obserwacje japońskich badaczy, w których opisują rolę tzw. reakcji desmoplastycznej w rozwoju raka jelita grubego poprzez niektóre białka z rodziny ADAM. W reakcji tej biorą udział m.in fibroblasty związane z nowotworem (CAFs), znajdujące się wśród komórek zrębu. Odgrywają one główną rolę w rozwoju mikrośrodowiska guza. CAFs powodują zwiększoną ekspresję ADAM9, 10, 12 i 17, a ekspresja ta jest związana z kategorią morfologiczną reakcji desmoplastycznej, która wpływa na złośliwość procesu rozrostowego przez wzrost proliferacji komórek nowotworowych [54].

Wśród innych adamalizyn, które wymienia się jako potencjalnie istotne $\mathrm{w}$ rozwoju i progresji raka jelita grubego, znajdują się także ADAM8 [55], ADAM9 [56, 57] czy ADAM15 [58].

Najnowsze badania skupiają się także na udziale microRNA (miRNA, miR) w patogenezie raka jelita grubego. Okazuje się, że miRNA oddziałuje również na białka z rodziny adamalizyn. Wykazano, że microRNA-552 może promować powstawanie przerzutów odległych raka jelita grubego przez wpływ na ADAM28 [59]. Natomiast miRNA-198 hamuje proliferację komórek i indukuje apoptozę komórek raka jelita grubego, wpływając na ścieżkę sygnałową związaną z ADAM28 i JAK-STAT [60]. Podobnie hamujący wpływ na powstawanie i progresję raka jelita grubego wydaje się wywoływać microRNA-30c, oddziałując na adamalizynę ADAM19 [61]. Istotne wydaje się doniesienie na temat zmniejszania oporności na leczenie 5-fluorouracylem u chorych raka jelita grubego przez microRNA-20b, który hamuje ekspresję ADAM9 i EGFR [62].

Adamalizyny biorą również udział w powstawaniu zjawiska chemiooporności raka jelita grubego. Między innymi dla białek ADAM10 i ADAM17 obserwowano wystąpienie oporności na leczenie 5- fluorouracylem oraz oxaliplatyną przerzutowego raka jelita grubego, co było związane z fuzją komórek nowotworowych, za którą odpowiada ADAM10 [63]. Ponadto w badaniach na liniach komórkowych także wykazano, że zwiększona aktywność ADAM17 powoduje oporność na chemioterapię z użyciem 5-fluorouracylu i oxaliplatyny [64].

\section{Podsumowanie}

Omówione wyżej dane pozwalają na postawienie hipotezy: czy wybrane białka $z$ rodziny ADAM mogłyby pełnić rolę biomarkerów nowotworów złośliwych przewodu pokarmowego? Autorzy starali się wykazać, że taką funkcję można przypisać szczególnie białkom ADAM10 i ADAM17. Białka te są wymieniane przez wielu badaczy jako istotne składowe procesów patogenetycznych wszystkich omawianych w tej publikacji nowotworów i stanowią wspólny mianownik szlaków o potwierdzonej roli w nowotworzeniu: aktywacji EGFR, TNF-a, VEGF. Należy jednak podkreślić, że liczne białka z rodziny ADAM są zaangażowane w rozwój nowotworów złośliwych przewodu pokarmowego na wielu etapach nowotworzenia, od procesu różnicowania się pierwszych klonów złośliwych, poprzez wzrost i progresję guza, tworzenie przerzutów odległych, zarówno przez swój bezpośredni wpływ na komórki raka, jak i przez oddziaływanie na mikrośrodowisko guza. Ponadto białka te prawdopodobnie stanowią istotne ogniwa patogenezy w szlakach o znanym znaczeniu epidemiologicznym: powiązaniu przewlekłego stanu zapalnego związanego z infekcją $H$. pylori w raku żołądka; wpływu otyłości i hiperinsulinemii na nowotworzenie; nowotworzeniu zależnym od zaburzenia równowagi oksydoredukcyjnej. Ponadto dysponujemy wynikami badań, które wskazują na możliwość skutecznej modulacji wpływu adamalizyn na nowotworzenie przez zastosowanie swoistych przeciwciał lub metod inżynierii genetycznej. Jak również doniesieniami wskazującymi, że skuteczność niektórych konwencjonalnych cytostatyków, mających zastosowanie w nowotworach złośliwych przewodu pokarmowego, jest związana z oddziaływaniem m.in. na aktywność adamalizyn.

Wydaje się, że prowadzenie dalszych, pogłębionych badań nad rolą białek rodziny ADAM w nowotworzeniu i możliwości ich wykorzystania jako punktów uchwytu dla nowych terapii jest uzasadnione. 


\section{Wykaz skrótów}

ADAM - białka zawierające domenę dezintegryny i metaloproteinazy (a disintegrin and metallo-proteinases), CAFs - fibroblasty związane z nowotworem (carcinoma associated fibroblasts), CEA - antygen karcynoembrionalny (carcinoembryonic antygen), EGF - naskórkowy czynnik wzrostu (epidermal growth factor), EGFR - receptor naskórkowego czynnika wzrostu (epidermal growth factor receptor), FGF - czynnik wzrostu fibroblastów (fibroblast growth factor), IL - interleukina (interleukin), MEK - kinazy aktywowane mitogenami (mitogen-activated protein kinases), mRNA - informacyjny (przekaźnikowy, matrycowy) RNA (messenger RNA), miRNA=microRNA - małe, jednoniciowe cząsteczki RNA (small non-coding RNA molecule), OS - czas przeżycia całkowitego (overal survival), p-ERK-ERK - kinazy regulowane sygnałem zewnątrzkomórkowym (extracellular signal-regulated kinases), PFS - czas przeżycia wolny od progresji (progression free survival), TGF- $\beta$ - transformujący czynnik wzrostu beta (transforming growth factor beta), TNF- $\alpha$ - czynnik martwicy nowotworu (tumor necrosis factor alfa), TNM - system służący do określenia zaawansowania nowotworu: guz, węzły, przerzuty (tumor, nodules, metastases), VEGF - naczyniowy śródbłonkowy czynnik wzrostu (vascular endothelial growth factor).

\section{Finansowanie}

Publikacja finansowana ze środków własnych uczelni Śląski Uniwersytet Medyczny. Publikacja finansowana z umowy nr PCN-1-065/K/0/Z.

\section{Konflikt interesów}

Autorki deklarują brak potencjalnych konfliktów interesów.

\section{Piśmiennictwo}

[1] Bray F., Ferlay J., Soerjomataram I., Siegel R.L., Torre L.A., Jemal A.: Global cancer statistics 2018: GLOBOCAN estimates of incidence and mortality worldwide for 36 cancers in 185 countries. CA Cancer J. Clin., 2018; 68: 394-424

[2] Duffy M.J., McKiernan E., O'Donovan N., McGowan P.M.: Role of ADAMs in cancer formation and progression. Clin. Cancer Res., 2009; 15: 1140-1144

[3] Walkiewicz K., Kozieł P., Bednarczyk M., Błażelonis A., Mazurek U., Muc-Wierzgoń M.: Expression of migration-related genes in human colorectal cancer and activity of a disintegrin and metalloproteinase 17. Biomed Res. Int., 2016; 2016: 8208904
[4] Walkiewicz K., Nowakowska-Zajdel E., Kozieł P., Muc-Wierzgoń M.: The role of some ADAM-proteins and activation of the insulin growth factor-related pathway in colorectal cancer. Cent. Eur. J. Immunol., 2018; 43: 109-113

[5] Fushida S., Oyama K., Kinoshita J., Yagi Y., Okamoto K., Tajima H., Ninomiya I., Fujimura T., Ohta T.: VEGF is a target molecule for peritoneal metastasis and malignant ascites in gastric cancer: Prognostic significance of VEGF in ascites and efficacy of antiVEGF monoclonal antibody. Onco. Targets Ther., 2013; 6: 14451451

[6] Gao M.Q., Kim B.G., Kang S., Choi Y.P., Yoon J.H., Cho N.H.: Human breast cancer-associated fibroblasts enhance cancer cell proliferation through increased TGF- $\alpha$ cleavage by ADAM17. Cancer Lett., 2013; 336: 240-246

[7] Mochizuki S., Okada Y.: ADAM28 as a target for human cancers. Curr. Pharm. Des., 2009; 15: 2349-2358

[8] Stawikowska R., Cudic M., Giulianotti M., Houghten R.A., Fields G.B., Minond D.: Activity of ADAM17 (a disintegrin and metalloprotease 17 ) is regulated by its noncatalytic domains and secondary structure of its substrates. J. Biol. Chem., 2013; 288: 22871-22879

[9] Jones J.C., Rustagi S., Dempsey P.J.: ADAM proteases and gastrointestinal function. Annu. Rev. Physiol., 2016; 78: 243-276

[10] Zhou Z., Ran Y.L., Hu H., Pan J., Li Z.F., Chen L.Z., Sun L.C., Peng L., Zhao X.L., Yu L. i wsp.: TM4SF3 promotes esophageal carcinoma metastasis via upregulating ADAM12m expression. Clin. Exp. Metastasis, 2008; 25: 537-548

[11] Liu H.B., Zhu Y., Yang Q.C., Shen Y., Zhang X.J., Chen H.: Expression and clinical significance of ADAM17 protein in esophageal squamous cell carcinoma. Genet. Mol. Res., 2015; 14: 43914398

[12] Lo P.H., Lung H.L., Cheung A.K., Apte S.S., Chan K.W., Kwong F.M., Ko J.M., Cheng Y., Law S., Srivastava G. i wsp.: Extracellular protease ADAMTS9 suppresses esophageal and nasopharyngeal carcinoma tumor formation by inhibiting angiogenesis. Cancer Res., 2010; 70: 5567-5576

[13] Kauttu T., Mustonen H., Vainionpää S., Krogerus L., Ilonen I., Räsänen J., Salo J., Puolakkainen P.: Disintegrin and metalloproteinases (ADAMs) expression in gastroesophageal reflux disease and in esophageal adenocarcinoma. Clin. Transl. Oncol., 2017; 19: $58-66$

[14] Yoshimura T., Tomita T., Dixon M.F., Axon A.T., Robinson P.A., Crabtree J.E.: ADAMs (a disintegrin and metalloproteinase) messenger RNA expression in Helicobacter pylori - infected, normal, and neoplastic gastric mucosa. J. Infect. Dis., 2002; 185: 332-340

[15] Wang Y.Y., Ye Z.Y., Li L., Zhao Z.S., Shao Q.S., Tao H.Q.: ADAM 10 is associated with gastric cancer progression and prognosis of patients. J. Surg. Oncol., 2011; 103: 116-123

[16] Shou Z.X., Jin X., Zhao Z.S.: Upregulated expression of ADAM17 is a prognostic marker for patients with gastric cancer. Ann. Surg., 2012; 256: 1014-1022

[17] Zhang T.C., Zhu W.G., Huang M.D., Fan R.H., Chen X.F.: Prog- 
nostic value of ADAM17 in human gastric cancer. Med. Oncol., 2012; 29: 2684-2690

[18] Aydin D., Bilici A., Yavuzer D., Kefeli U., Tan A., Ercelep O., Mert A., Yuksel S., Ozcelik M., Isik D. i wsp.: Prognostic significance of ADAM17 expression in patients with gastric cancer who underwent curative gastrectomy. Clin. Transl. Oncol., 2015; 17: 604-611

[19] Li W., Wang D., Sun X., Zhang Y., Wang L., Suo J.: ADAM17 promotes lymph node metastasis in gastric cancer via activation of the Notch and Wnt signaling pathways. Int. J. Mol. Med., 2019; 43: 914-926

[20] Ebi M., Kataoka H., Shimura T., Kubota E., Hirata Y., Mizushima T., Mizoshita T., Tanaka M., Mabuchi M., Tsukamoto H. i wsp.: TGF $\beta$ induces proHB-EGF shedding and EGFR transactivation through ADAM activation in gastric cancer cells. Biochem. Biophys. Res. Commun., 2010; 402: 449-454

[21] Nakagawa M., Nabeshima K., Asano S., Hamasaki M., Uesugi N., Tani H., Yamashita Y., Iwasaki H.: Up-regulated expression of ADAM17 in gastrointestinal stromal tumors: Coexpression with EGFR and EGFR ligands. Cancer Sci., 2009; 100: 654-662

[22] Carl-McGrath S., Lendeckel U., Ebert M., Roessner A., Röcken C.: The disintegrin-metalloproteinases ADAM9, ADAM12, and ADAM15 are upregulated in gastric cancer. Int. J. Oncol., 2005; 26: $17-24$

[23] Kim K.E., Song H., Hahm C., Yoon S.Y., Park S., Lee H.R., Hur D.Y., Kim T., Kim C.H., Bang S.I. i wsp.: Expression of ADAM33 is a novel regulatory mechanism in IL-18-secreted process in gastric cancer. J. Immunol., 2009; 182: 3548-3555

[24] Kim J.M., Jeung H.C., Rha S.Y., Yu E.J., Kim T.S., Shin Y.K., Zhang X., Park K.H., Park S.W., Chung H.C. i wsp.: The effect of disintegrin-metalloproteinase ADAM9 in gastric cancer progression. Mol. Cancer Ther., 2014; 13: 3074-3085

[25] Wang J., Zhou Y., Fei X., Chen X., Yan J., Liu B., Zhu Z.: ADAM9 functions as a promoter of gastric cancer growth which is negatively and post-transcriptionally regulated by miR-126. Oncol. Rep., 2017; 37: 2033-2040

[26] Huang J., Bai Y., Huo L., Xiao J., Fan X., Yang Z., Chen H., Yang Z.: Upregulation of a disintegrin and metalloprotease 8 is associated with progression and prognosis of patients with gastric cancer. Transl. Res., 2015; 166: 602-613

[27] Chung H.W., Kim J.J., Choi J.I., Lee H.R., Lim J.B.: A disintegrin and metalloproteinase 8 as a potential blood biomarker for early diagnosis of gastric cancer. Yonsei Med. J., 2019; 60: 713-719

[28] Chen H., Wang S.: Clinical significance of ADAM29 promoting the invasion and growth of gastric cancer cells in vitro. Oncol. Lett., 2018; 16: 1483-1490

[29] Ilic M, Ilic I.: Epidemiology of pancreatic cancer. World J. Gastroenterol., 2016; 22: 9694-9705

[30] Stewart B.W., Wild C.P.: World cancer report 2014. International Agency for Research on Cancer, Lyon 2014

[31] Gaida M.M., Haag N., Günther F., Tschaharganeh D.F., Schirmacher P., Friess H., Giese N.A., Schmidt J., Wente M.N.: Expression of A disintegrin and metalloprotease 10 in pancreatic carci- noma. Int. J. Mol. Med., 2010; 26: 281-288

[32] Ringel J., Jesnowski R., Moniaux N., Lüttges J., Ringel J., Choudhury A., Batra S.K., Klöppel G., Löhr M.: Aberrant expression of a disintegrin and metalloproteinase 17/tumor necrosis factor- $\alpha$ converting enzyme increases the malignant potential in human pancreatic ductal adenocarcinoma. Cancer Res., 2006; 66: 9045-9053

[33] Valkovskaya N., Kayed H., Felix K., Hartmann D., Giese N.A., Osinsky S.P., Friess H., Kleeff J.: ADAM8 expression is associated with increased invasiveness and reduced patient survival in pancreatic cancer. J. Cell. Mol. Med., 2007; 11: 1162-1174

[34] Valkovskaya N.V: Hypoxia-dependent expression of ADAM8 in human pancreatic cancer cell lines. Exp. Oncol., 2008; 30: 129132

[35] Puolakkainen P., Koski A., Vainionpää S., Shen Z., Repo H., Kemppainen E., Mustonen H., Seppänen H.: Anti-inflammatory macrophages activate invasion in pancreatic adenocarcinoma by increasing the MMP9 and ADAM8 expression. Med. Oncol., 2014; 31: 884

[36] Gao Y., Yu X., Zhang F., Dai J.: Propofol inhibits pancreatic cancer progress under hypoxia via ADAM8. J. Hepatobiliary Pancreat. Sci., 2019; 26: 219-226

[37] Grützmann R., Lüttges J., Sipos B., Ammerpohl O., Dobrowolski F., Alldinger I., Kersting S., Ockert D., Koch R., Kalthoff H. i wsp.: ADAM9 expression in pancreatic cancer is associated with tumour type and is a prognostic factor in ductal adenocarcinoma. Br. J. Cancer, 2004; 90: 1053-1058

[38] Oria V.O., Lopatta P., Schmitz T., Preca B.T., Nyström A., Conrad C., Bartsch J.W., Kulemann B., Hoeppner J., Maurer J. i wsp.: ADAM9 contributes to vascular invasion in pancreatic ductal adenocarcinoma. Mol. Oncol., 2019; 13: 456-479

[39] Duan X., Mao X., Sun W.: ADAM15 is involved in MICB shedding and mediates the effects of gemcitabine on MICB shedding in PANC-1 pancreatic cancer cells. Mol. Med. Rep., 2013; 7: 991-997

[40] Woods N., Trevino J., Coppola D., Chellappan S., Yang S., Padmanabhan J.: Fendiline inhibits proliferation and invasion of pancreatic cancer cells by interfering with ADAM10 activation and $\beta$-catenin signaling. Oncotarget, 2015; 6: 35931-35948

[41] Ye J., Yuen S.M., Murphy G., Xie R., Kwok H.F.: Anti-tumor effects of a 'human \& mouse cross-reactive' anti-ADAM17 antibody in a pancreatic cancer model in vivo. Eur. J. Pharm. Sci., 2017; 110: $62-69$

[42] Schlomann U., Koller G., Conrad C., Ferdous T., Golfi P., Garcia A.M., Höfling S., Parsons M., Costa P., Soper R. i wsp.: ADAM8 as a drug target in pancreatic cancer. Nat. Commun., 2015; 6: 6175

[43] Moss M.L., Minond D.: Recent advances in ADAM17 research: A promising target for cancer and inflammation. Mediators Inflamm., 2017; 2017: 9673537

[44] Terzić J., Grivennikov S., Karin E., Karin M.: Inflammation and colon cancer. Gastroenterology, 2010; 138: 2101-2114

[45] Blanchot-Jossic F., Jarry A., Masson D., Bach-Ngohou K., Paineau J., Denis M.G., Laboisse C.L., Mosnier J.F.: Up-regulated 
expression of ADAM17 in human colon carcinoma: Co-expression with EGFR in neoplastic and endothelial cells. J. Pathol., 2005; 207: 156-163

[46] Das S., Czarnek M., Bzowska M., Mężyk-Kopeć R., Stalińska K., Wyroba B., Sroka J., Jucha J., Deneka D., Stokłosa P. i wsp.: ADAM17 silencing in mouse colon carcinoma cells: The effect on tumoricidal cytokines and angiogenesis. PLoS One, 2012; 7 : e50791

[47] Lin H.M., Chatterjee A., Lin Y.H., Anjomshoaa A., Fukuzawa R., McCall J.L., Reeve A.E.: Genome wide expression profiling identifies genes associated with colorectal liver metastasis. Oncol. Rep., 2007; 17: 1541-1549

[48] Van Schaeybroeck S., Kyula J.N., Fenton A., Fenning C.S., Sasazuki T., Shirasawa S., Longley D.B., Johnston P.G.: Oncogenic Kras promotes chemotherapy-induced growth factor shedding via ADAM17. Cancer Res., 2011; 71: 1071-1080

[49] Rios-Doria J., Sabol D., Chesebrough J., Stewart D., Xu L., Tammali R., Cheng L., Du Q., Schifferli K., Rothstein R. i wsp.: A monoclonal antibody to ADAM17 inhibits tumor growth by inhibiting EGFR and non-EGFR-mediated pathways. Mol. Cancer Ther., 2015; 14: 1637-1649

[50] Dempsey P.J.: Role of ADAM10 in intestinal crypt homeostasis and tumorigenesis. Biochim. Biophys. Acta, 2017; 1864: 22282239

[51] Knösel T., Emde A., Schlüns K., Chen Y., Jürchott K., Krause M., Dietel M., Petersen I.: Immunoprofiles of 11 biomarkers using tissue microarrays identify prognostic subgroups in colorectal cancer. Neoplasia, 2005; 7: 741-747

[52] Walkiewicz K., Strzelczyk J., Waniczek D., Biernacki K., MucWierzgoń M., Copija A., Nowakowska-Zajdel E.: Adamalysines as biomarkers and a potential target of therapy in colorectal cancer patients: Preliminary results. Dis. Markers, 2019; 2019: 5035234

[53] Nowakowska-Zajdel E., Mazurek U., Wierzgoń J., Kokot T., Fatyga E., Ziółko E., Klakla K., Błazelonis A., Waniczek D., Głogowski Ł. i wsp.: Expression of ADAM28 and IGFBP-3 genes in patients with colorectal cancer - a preliminary report. Int. J. Immunopathol. Pharmacol., 2013; 26: 223-228

[54] Mochizuki S., Ao T., Sugiura T., Yonemura K., Shiraishi T., Kaji- wara Y., Okamoto K., Shinto E., Okada Y., Ueno H.: Expression and function of a disintegrin and metalloproteinases in cancerassociated fibroblasts of colorectal cancer. Digestion, 2020; 101: 18-24

[55] Yang Z., Bai Y., Huo L., Chen H., Huang J., Li J., Fan X., Yang Z., Wang L., Wang J.: Expression of A disintegrin and metalloprotease 8 is associated with cell growth and poor survival in colorectal cancer. BMC Cancer, 2014; 14: 568

[56] Hirao T., Nanba D., Tanaka M., Ishiguro H., Kinugasa Y., Doki Y., Yano M., Matsuura N., Monden M., Higashiyama S.: Overexpression of ADAM9 enhances growth factor-mediated recycling of E-cadherin in human colon cancer cell line HT29 cells. Exp. Cell Res., 2006; 312: 331-339

[57] Mazzocca A., Coppari R., De Franco R., Cho J.Y., Libermann T.A., Pinzani M., Toker A.: A secreted form of ADAM9 promotes carcinoma invasion through tumor-stromal interactions. Cancer Res., 2005; 65: 4728-4738

[58] Toquet C., Colson A., Jarry A., Bezieau S., Volteau C., Boisseau P., Merlin D., Laboisse C.L., Mosnier J.F.: ADAM15 to a $5 \beta 1$ integrin switch in colon carcinoma cells: A late event in cancer progression associated with tumor dedifferentiation and poor prognosis. Int. J. Cancer, 2012; 130: 278-287

[59] Wang J., Li H., Wang Y., Wang L., Yan X., Zhang D., Ma X., Du Y., Liu X., Yang Y.: MicroRNA-552 enhances metastatic capacity of colorectal cancer cells by targeting a disintegrin and metalloprotease 28. Oncotarget, 2016; 7: 70194-70210

[60] Li L.X., Lam I.H., Liang F.F., Yi S.P., Ye L.F., Wang J.T., Guo W.W., Xu M.: MiR-198 affects the proliferation and apoptosis of colorectal cancer through regulation of ADAM28/JAK-STAT signaling pathway. Eur. Rev. Med. Pharmacol. Sci., 2019; 23: 1487-1493

[61] Zhang Q., Yu L., Qin D., Huang R., Jiang X., Zou C., Tang Q., Chen Y., Wang G., Wang X., Gao X.: Role of microRNA-30c targeting ADAM19 in colorectal cancer. PLoS One, 2015; 10: e0120698

[62] Fu Q., Cheng J., Zhang J., Zhang Y., Chen X., Luo S., Xie J.: MiR-20b reduces 5-FU resistance by suppressing the ADAM9/ EGFR signaling pathway in colon cancer. Oncol. Rep., 2017; 37: 123-130

[63] Carloni V., Mazzocca A., Mello T., Galli A., Capaccioli S.: Cell fusion promotes chemoresistance in metastatic colon carcinoma. Oncogene, 2013; 32: 2649-2660

[64] Kyula J.N., Van Schaeybroeck S., Doherty J., Fenning C.S., Longley D.B., Johnston P.G.: Chemotherapy-induced activation of ADAM-17: A novel mechanism of drug resistance in colorectal cancer. Clin. Cancer Res., 2010; 16: 3378-3389 